\title{
Sample size for estimation of the Pearson correlation coefficient in cherry tomato tests
}

\author{
Bruno Giacomini Sari ${ }^{*}$ Alessandro Dal'Col Lúcio ${ }^{2}$ Cinthya Souza Santana ${ }^{1}$ \\ Dionatan Ketzer Krysczun ${ }^{1}$ André Luís Tischler ${ }^{3}$ Lucas Drebes $^{3}$
}

'Programa de Pós-graduação em Agronomia, Universidade Federal de Santa Maria (UFSM), Avenida Roraima, 1000, Camobi, 97105-900, Santa Maria, RS, Brasil. E-mail: brunosari@hotmail.com. *Corresponding author.

${ }^{2}$ Departamento de Fitotecnia, Centro de Ciências Rurais (CCR), Universidade Federal de Santa Maria (UFSM), Santa Maria, RS, Brasil.

${ }^{3}$ Departamento de Agronomia, Centro de Ciências Rurais (CCR), Universidade Federal de Santa Maria (UFSM), Santa Maria, RS, Brasil.

\begin{abstract}
The aim of this study was to determine the required sample size for estimation of the Pearson coefficient of correlation between cherry tomato variables. Two uniformity tests were set up in a protected environment in the spring/summer of 2014. The observed variables in each plant were mean fruit length, mean fruit width, mean fruit weight, number of bunches, number of fruits per bunch, number of fruits, and total weight of fruits, with calculation of the Pearson correlation matrix between them. Sixty eight sample sizes were planned for one greenhouse and 48 for another, with the initial sample size of 10 plants, and the others were obtained by adding five plants. For each planned sample size, 3000 estimates of the Pearson correlation coefficient were obtained through bootstrap re-samplings with replacement. The sample size for each correlation coefficient was determined when the 95\% confidence interval amplitude value was less than or equal to 0.4. Obtaining estimates of the Pearson correlation coefficient with high precision is difficult for parameters with a weak linear relation. Accordingly, a larger sample size is necessary to estimate them. Linear relations involving variables dealing with size and number of fruits per plant have less precision. To estimate the coefficient of correlation between productivity variables of cherry tomato, with a confidence interval of $95 \%$ equal to 0.4 , it is necessary to sample 275 plants in a $250 \mathrm{~m}^{2}$ greenhouse, and 200 plants in a $200 \mathrm{~m}^{2}$ greenhouse.

Key words: Solanum lycopersicum var. cerasiforme, sampling, resampling, bootstrap.
\end{abstract}

Tamanho de amostra para estimar o coeficiente de correlação

de Pearson em ensaios com tomate cereja

RESUMO: O objetivo deste trabalho foi determinar o tamanho de amostra necessário para estimar o coeficiente de correlação de Pearson entre variáveis do tomate cereja. Foram instalados dois ensaios de uniformidade em ambiente protegido na primavera/verão de 2014. As variáveis observadas em cada planta foram comprimento médio de fruto, largura média de fruto, peso médio de fruto, número de cachos, número de frutos por cacho, número de frutos e peso total de frutos, sendo calculada a matriz de correlação de Pearson entre elas. Foram planejados 68 tamanhos de amostra em uma estufa e 48 em outra, com tamanho inicial composto de 10 plantas e os demais obtidos acrescentando cinco plantas. Para cada tamanho de amostra planejado foram obtidas 3000 estimativas do coeficiente de correlação de Pearson através de reamostragens "bootstrap" com reposição. O tamanho de amostra de cada coeficiente de correlação foi determinado quando o valor da amplitude do intervalo de confiança de 95\% foi menor ou igual a 0,4. A obtenção das estimativas do coeficiente de correlação de Pearson com elevada precisão é dificil para caracteres com relação linear fraca e, consequentemente, maior é o tamanho amostra necessário para estimalos. As relações lineares envolvendo as variáveis relacionadas com o tamanho e o número de frutos por planta tem menor precisão. Para estimar o coeficiente de correlação entre variáveis produtivas do tomate cereja, com intervalo de confiança de 95\% igual a 0,4, é necessário amostrar 275 plantas na estufa de $250 \mathrm{~m}^{2}$, e 200 plantas na estufa de $200 \mathrm{~m}^{2}$.

Palavras-chave: Solanum lycopersicum var. cerasiforme, amostragem, reamostragem, "bootstrap".

\section{INTRODUCTION}

When several variables are measured in an essay, there is a possibility to study the linear relation between them. This type of information is mainly used in plant breeding and involves identifying variables that can be used in indirect selection of superior genotypes (CRUZ \& REGAZZI, 1997). In addition, knowledge of the relation between productivity parameters and total fruit yield may assist in the improvement or choice of management practices. 
Pearson correlation coefficient is a dimensionless measure that determines a linear relation between two variables. Its value varies from -1 , when there is a perfect negative linear relation, to +1 , when there is a perfect positive linear relation. The closer this value to zero, the smaller is the degree of linear relation. From the Pearson correlation coefficient, many other statistics are calculated, such as partial correlation, direct and indirect effects between variables in track analysis, and canonical correlation (HAIR et al., 2005). Thus, the precision of these statistics depends on accuracy of the estimate of Pearson's correlation coefficient.

Sample size has a large impact on statistical significance and interpretation of a statistical result. In large samples, the coefficients of low magnitude tend to show statistical significance, even when the relation between the parameters is not important from the practical point of view. Nevertheless, when the sample size is small, the reliability of the estimates is low and may not represent the true relation between two variables (HAIR et al., 2005; CARGNELUTTI FILHO et al., 2010; CARGNELUTTI FILHO et al., 2011; CARGNELUTTI FILHO et al., 2012). Hence, we realized that an adequate sample size with acceptable accuracy is important.

The confidence interval of the Pearson correlation coefficient can be estimated from the sampling distribution transformed by Fischer (FERREIRA, 2009; CARGNELUTTI FILHO et al., 2011). Another way to obtain it is by means of bootstrap confidence intervals with replacement. In this methodology, there is no need to know the variable's probability distribution, and this approach is effective in the case of variables with an unknown or non normal distribution (CARGNELUTTI FILHO et al., 2010; CARGNELUTTI FILHO et al., 2012). This methodology is of great value because it can be used to determine the confidence interval amplitude of any variable and for any cultivated plant. The sample size required for estimation of the mean of parameters is common in the literature, but there are few studies that determine the sample size needed to estimate the Pearson correlation coefficient (CARGNELUTTI FILHO et al., 2010; CARGNELUTTI FILHO et al., 2011; CARGNELUTTI FILHO et al., 2012). In the specific case of olive groves, studies determining a sample size for estimation of the Pearson correlation coefficient are practically nonexistent. Studies are limited to only determine a sample size for the mean of parameters (SILVA et al., 2009; SANTOS et al., 2010; HAESBAERT et al., 2011; SILVA et al., 2011; LÚCIO et al., 2012).
The appropriate sample size will be related to the accuracy of the estimate of Pearson's correlation coefficient. In the case of cherry tomatoes, there are no studies in the literature that make this determination. Consequently, the aim of the present study was to determine the sample size for estimation of the Pearson correlation coefficient between productivity variables of cherry tomato.

\section{MATERIALS AND METHODS}

Two uniformity tests were carried out in plastic greenhouses in the Plant Science Department of the Universidade Federal de Santa Maria (latitude $29^{\circ} 43^{\prime} \mathrm{S}$, longitude $53^{\circ} 43^{\prime} \mathrm{W}$ and $95 \mathrm{~m}$ altitude). Greenhouses were covered with a low density polyethylene (LDPE) film, with 150 micron thickness and an anti UV additive, placed in the north-south direction, and the greenhouses had the following dimensions: 1) $20 \times 10 \mathrm{~m}\left(200 \mathrm{~m}^{2}\right), 3 \mathrm{~m}$ right foot and $4 \mathrm{~m}$ in the central part; 2) $25 \times 10 \mathrm{~m}\left(250 \mathrm{~m}^{2}\right), 4 \mathrm{~m}$ right foot and $5.5 \mathrm{~m}$ in the central part. Climate at the site of the experiments is classified as Cfa, and the soil is classified from Paleudalf (EMBRAPA, 2006).

A soil correction in the two greenhouses was performed 30 days before planting and served to raise $\mathrm{pH}$ to 6.5 and the phosphorus level to $300 \mathrm{mg}$ $\mathrm{dm}^{-3}$. Next, eight ridges were constructed in each greenhouse, with $0.20 \mathrm{~m}$ height and $0.30 \mathrm{~m}$ width, and spaced at $1 \mathrm{~m}$. These ridges were covered with a mulching black opaque LDPE film. Planting fertilization was conducted by means of $150 \mathrm{~kg} \mathrm{ha}^{-1} \mathrm{~N}$, $250 \mathrm{~kg} \mathrm{ha}^{-1} \mathrm{P}$, and $125 \mathrm{~kg} \mathrm{ha}^{-1} \mathrm{~K}$ for each greenhouse. The cover fertilization was performed every 23 days, with $30 \mathrm{~kg} \mathrm{ha}^{-1} \mathrm{~N}, 15 \mathrm{~kg} \mathrm{ha}^{-1} \mathrm{P}$, and $30 \mathrm{~kg} \mathrm{ha}^{-1} \mathrm{~K}$. All the procedures were carried out based on soil chemical analysis and according to recommendations of the Official Network of Soil and Plant Tissue Analysis Laboratories of the states of Rio Grande do Sul and Santa Catarina (ROLAS, 2004).

The seedlings were Lily Hybrid Cherry tomatoes, and the transplant took place in the spring/ summer season, on October 26, 2014, during the first flowering. Spacing between seedlings was $0.5 \mathrm{~m}$. Plants were vertically staked with a ribbon and driven on a double stem with elimination of lateral shoots. Every 14 days, sprays of calcium, boron, fungicides, and insecticides were administered to control pests, diseases, and physiological disturbances such as the "blossom end rot" of fruits.

All the plants in both greenhouses were evaluated, totaling 247 plants in the $200 \mathrm{~m}^{2}$ greenhouse and 347 in the $250 \mathrm{~m}^{2}$ greenhouse. All 
the fruits were harvested, and the following variables were determined: total weight fruit (TWF), mean fruit length (MFL), mean fruit width (MFWi), mean fruit weight (MFW), number of bunches per plant (NBP), number of fruits per plant (NFP), and the number of fruits per bunch (NFB). Variables MFWi and MFL were measured in centimeters with a caliper. MFW and TWF were measured in grams using a scale with $0.01 \mathrm{~g}$ precision.

From the observed data, two Pearson correlation matrices were constructed, one for each for greenhouse. The correlation coefficients were tested for their significance by Student's $t$ test at an error probability of 5\%. The third matrix (matrix of means) was compiled from the mean values of the Pearson correlation coefficients of the two matrices previously mentioned. A total of 68 sample sizes were planned for the $250 \mathrm{~m}^{2}$ greenhouse and 48 for the $200 \mathrm{~m}^{2}$ greenhouse. The initial size was 10 plants, and the others were calculated by adding five plants. For each of them, 3000 estimates of the Pearson correlation coefficient were obtained through bootstrap resampling with replacement. Later, from the 3000 estimates, we calculated the minimum value, $2.5 \%$ percentile, mean, $97.5 \%$ percentile, maximum value, and the $95 \%$ confidence interval (the difference between the $97.5 \%$ and $2.5 \%$ percentiles). The confidence interval, which represents the variation caused by the variable's random behaviour can be represented by 1000 re-samplings; the larger the number of re-samplings, the more accurate is the interval (FERREIRA, 2009). Then, the use of the 3000 resamplings had the objective to obtain intervals with high precision.

The amplitude of the confidence interval determines variability of the correlation coefficients estimated by means of different sample sizes. The optimal sample size to estimate the Pearson correlation coefficient was determined when the amplitude value of the $95 \%$ bootstrap confidence interval was less than or equal to 0.4 (Figure 1a). We also calculated the mean of each of the 21 sample size estimates obtained for each of the two matrices. Data processing and statistical analysis were conducted using the $\mathrm{R}$ software (R DEVELOPMENT CORE TEAM, 2012) and Microsoft Office Excel ${ }^{\circledR}$.

\section{RESULTS AND DISCUSSION}

The Pearson correlation coefficients of the 21 pairs of parameters varied between -0.019 and 0.97 in the $200 \mathrm{~m}^{2}$ greenhouse and between -0.083 and 0.963 in the $250 \mathrm{~m}^{2}$ greenhouse. Of these, $20 \mathrm{had}$ statistical significance in the $200 \mathrm{~m}^{2}$ greenhouse and 12 in the $250 \mathrm{~m}^{2}$ greenhouse (Table 1). We reported that the Pearson correlation coefficients, even at low magnitude, were statistically significant, as a consequence of the large number of observations (347 in the $250 \mathrm{~m}^{2}$ greenhouse and 247 in the $200 \mathrm{~m}^{2}$ greenhouse). This finding should be interpreted with caution because a statistical test often indicates the presence of a linear relation between variables, when in fact this relation is of no practical importance (HAIR et al., 2005; CARGNELUTTI FILHO et al., 2010; CARGNELUTTI FILHO et al., 2011; CARGNELUTTI FILHO et al., 2012).

The association between fruit size variables (MFL, MFWi, and MFW) and the number of fruits per plant (NBP, NFP, and NFB) differed between the greenhouses, resulting in different Pearson correlation coefficients, both in magnitude and sign. Hence, the use of a matrix mean may not provide an adequate Pearson correlation coefficient; and consequently, the sample size calculated from it may not be reliable. Thus, we chose to determine the sample size for each of the trials separately (Table 1).

The amplitudes of the $95 \%$ confidence interval-obtained from 3000 bootstrap re-samplings with replacement-revealed that the Pearson correlation coefficient estimate is more accurate for variables with a strong linear relation than for those with a weak linear relation. With the increasing sample size, the confidence interval amplitude is still high in large samples when the correlation coefficient is close to zero (Figure 1). The estimated sample sizes for the 21 correlation coefficients were inversely proportional to the magnitude of the Pearson correlation coefficient in both greenhouses $\left(\mathrm{r}=-0.95\right.$ in the $250 \mathrm{~m}^{2}$ greenhouse and $\mathrm{r}=-0.91$ in the $200 \mathrm{~m}^{2}$ greenhouse), confirming that the weaker the linear relation between variables (Pearson correlation coefficients close to zero), the larger is the sample size needed for its estimation.

A suitable sample size is necessary, especially when the correlation coefficient is close to zero, because there is great variability of magnitude and sign inversion (Table 2); this situation definitely compromises the statistical analysis. CARGNELUTTI FILHO et al. (2010), after studying the linear relation between corn parameters, reported that an inadequate sample size may be linked to the discrepancies in results of scientific publications. Because of significance of the mathematical sign for interpretation of the Pearson correlation coefficient, the use of a suitable sample size for its determination 


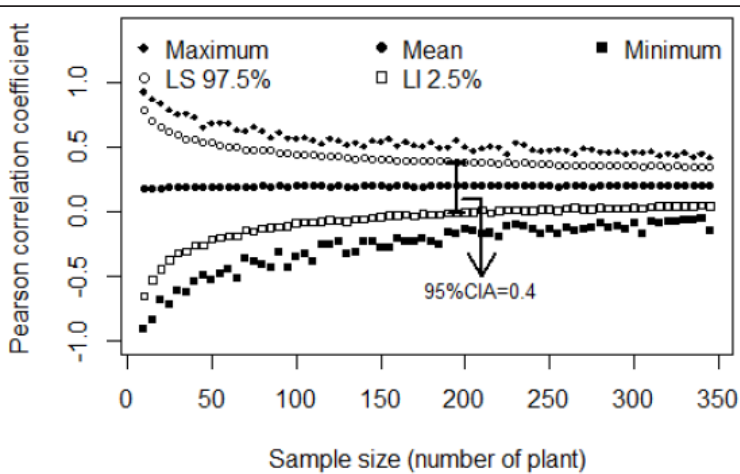

(A)

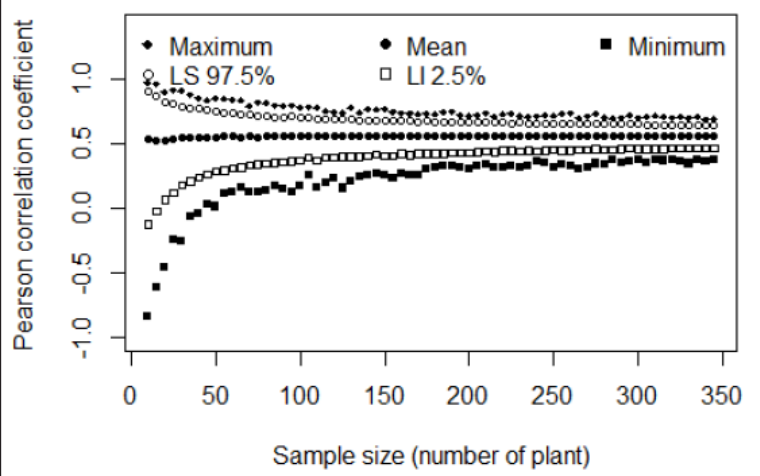

(C)

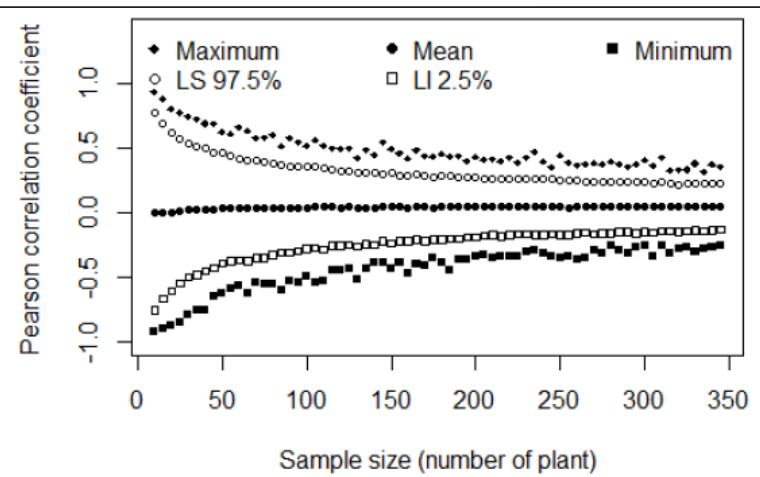

(B)

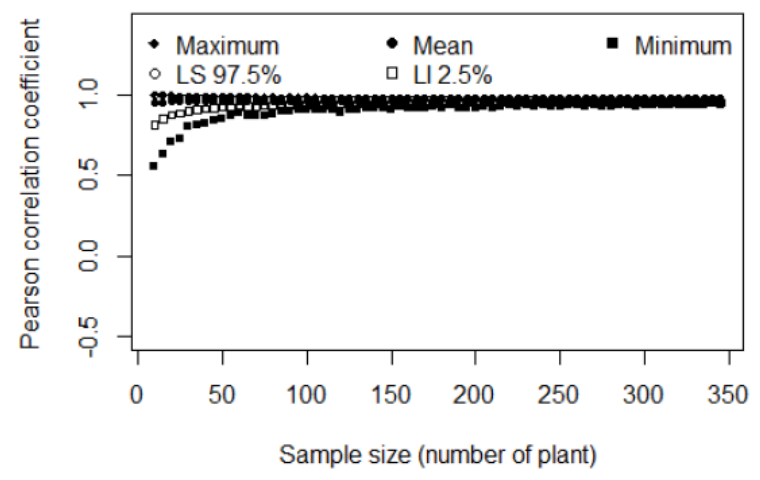

(D)

Figure 1 - Maximum, 97.5\% percentile (LS 97.5\%), mean, 2.5\% percentile (LI 2.5\%), and the minimum for 3000 "bootstrap" estimates of the Pearson coefficient of correlation between the total weight of fruits and the mean length of fruits (A), between the mean width of a fruit and the number of fruits per plant (B), between total fruit weight and number of fruits per bunch (C), and between total fruit weight and number of fruits per plant (D) in the $250 \mathrm{~m}^{2}$ greenhouse.

is highly relevant, even more than the required sample size for mean estimation.

In the case of cherry tomatoes, we reported that the use of small samples is even more detrimental for the study of linear relations involving fruit size variables (MFL, MFWi, and MFW) and the number of fruits per plant (NBP, NFP, and NFB). For example, the estimate of the correlation between variables MFL and NBP obtained in the $250 \mathrm{~m}^{2}$ and $200 \mathrm{~m}^{2}$ greenhouses was -0.083 and 0.133 , respectively. When the sample consists of only 10 plants, the amplitude of the $95 \%$ confidence interval of the 3000 bootstrap estimates with replacement ranged from -0.744 to 0.657 in the $250 \mathrm{~m}^{2}$ greenhouse and from -0.699 to 0.764 in the $200 \mathrm{~m}^{2}$ greenhouse. These results showed that at reduced sample sizes, the inferences about relations of variables can be contradictory, compromising interpretation of the results. This problem did not occur between variables TWF and NFP. In this case, the correlation coefficients obtained in the $250 \mathrm{~m}^{2}$ and $200 \mathrm{~m}^{2}$ greenhouses were 0.963 and 0.970 , respectively. The $95 \%$ confidence interval of the estimates varied between 0.810 and 0.995 in the $250 \mathrm{~m}^{2}$ greenhouse, and between 0.864 and 0.995 in the $200 \mathrm{~m}^{2}$ greenhouse (Table 2).

The sample size needed to estimate the Pearson coefficient of correlation between productivity variables of cherry tomato, with a $95 \%$ confidence interval equal to 0.4 , varied between 10 and 275 in the $250 \mathrm{~m}^{2}$ greenhouse and between 10 and 200 in the 
Table 1 - The matrix of Pearson correlation coefficients (upper diagonal) and sample sizes (lower diagonal) for 21 pairs of variables obtained in two trials and from their mean.

\begin{tabular}{|c|c|c|c|c|c|c|c|}
\hline & TWF & MFL & MFWi & MFW & NBP & NFP & NFB \\
\hline $\mathrm{TWF}^{1}$ & & $0.204^{*}$ & $0.287^{*}$ & $0.239^{*}$ & $0.829 *$ & $0.963^{*}$ & $0.564^{*}$ \\
\hline MFL & 195 & & $0.911^{*}$ & $0.873^{*}$ & -0.083 & -0.027 & 0.085 \\
\hline MFWi & 205 & 10 & & $0.887^{*}$ & -0.031 & 0.052 & $0.163^{*}$ \\
\hline MFW & 170 & 15 & 15 & & -0.080 & -0.027 & 0.081 \\
\hline NBP & 30 & 225 & 255 & 205 & & $0.876^{*}$ & 0.091 \\
\hline NFP & 10 & 240 & 275 & 245 & 20 & & $0.559^{*}$ \\
\hline NFB & 70 & 150 & 150 & 145 & 195 & 70 & \\
\hline \multicolumn{8}{|c|}{ } \\
\hline TWF & & $0.420^{*}$ & $0.478^{*}$ & $0.598^{*}$ & $0.772^{*}$ & $0.970^{*}$ & $0.572^{*}$ \\
\hline MFL & 110 & & $0.915^{*}$ & $0.767^{*}$ & $0.133^{*}$ & $0.252^{*}$ & $0.241^{*}$ \\
\hline MFWi & 100 & 10 & & $0.795^{*}$ & $0.171^{*}$ & $0.312^{*}$ & $0.289^{*}$ \\
\hline MFW & 90 & 25 & 25 & & $0.282^{*}$ & $0.391^{*}$ & $0.270^{*}$ \\
\hline NBP & 30 & 175 & 175 & 200 & & $0.802^{*}$ & -0.019 \\
\hline NFP & 10 & 140 & 140 & 150 & 25 & & $0.580^{*}$ \\
\hline NFB & 75 & 120 & 125 & 145 & 130 & 70 & \\
\hline \multicolumn{8}{|c|}{ 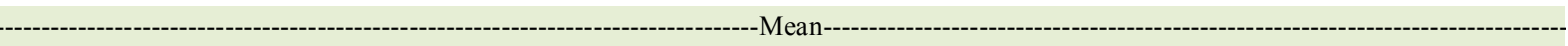 } \\
\hline FWB & & 0.312 & 0.383 & 0.419 & 0.801 & 0.966 & 0.568 \\
\hline MFL & 153 & & 0.913 & 0.820 & 0.024 & 0.112 & 0.163 \\
\hline MFWi & 153 & 10 & & 0.841 & 0.069 & 0.182 & 0.226 \\
\hline MFW & 130 & 20 & 20 & & 0.101 & 0.181 & 0.176 \\
\hline NBP & 30 & 200 & 215 & 203 & & 0.839 & 0.036 \\
\hline NFP & 10 & 190 & 208 & 198 & 23 & & 0.570 \\
\hline NFB & 73 & 135 & 138 & 145 & 163 & 70 & \\
\hline
\end{tabular}

${ }^{1} \mathrm{TWF}=$ total weight fruit $(\mathrm{g}), \mathrm{MFL}=$ mean fruit length per plant $(\mathrm{cm}), \mathrm{MFWi}=$ mean fruit width per plant $(\mathrm{cm}), \mathrm{MFW}=$ mean fruit weight per plant $(\mathrm{g})$; NBP = the number of bunches per plant, NFP = the number of fruits per plant, NFB = the number of fruits per bunch. *Significant according to the $t$ test $(\mathrm{P}<0.05)$, with 345 degrees of freedom in the $250 \mathrm{~m}^{2}$ greenhouse and 245 degrees of freedom in the $200 \mathrm{~m}^{2}$ greenhouse.

$200 \mathrm{~m}^{2}$ greenhouse (Table 1). Therefore, a sample size of 275 plants in the $250 \mathrm{~m}^{2}$ greenhouse and 200 plants in the $200 \mathrm{~m}^{2}$ greenhouse allows for estimating the coefficient of correlation between the cherry tomato's productivity variables with a $95 \%$ confidence interval of at least 0.4 , regardless of the relation between the parameters being studied. The use of this amplitude of the confidence interval to determine a sample size is justified because at this value, the amplitude tends to stabilize when the correlation coefficient is of low magnitude (Figure 1a).

Sample sizes determined by means of the same amplitude of a confidence interval have different precision values (this value is greater in the correlation coefficients of greater magnitude than in those with lower magnitude). Hence, it is important to highlight that if a researcher wants to estimate the Pearson correlation coefficient with the same precision, the sample size for each analysis should be different. If the same sample size is used, the precision estimation will not be the same. The better amplitude definition of the $95 \%$ confidence interval will be selected by each researcher according to the experimental precision of its estimates.

\section{CONCLUSION}

The sample size should be larger for determining a linear relation of the variables associated with the size and number of fruits per plant, owing to the low magnitude of this correlation.

To estimate the Pearson coefficients of correlation between cherry tomato variables with a $95 \%$ confidence interval amplitude equal to 0.4 , it is necessary to sample 275 plants in the $250 \mathrm{~m}^{2}$ greenhouse and 200 plants in the $200 \mathrm{~m}^{2}$ greenhouse. 
Table 2 - Values of the $2.5 \%$ percentile (upper diagonal) and $97.5 \%$ percentile (lower diagonal) of the Pearson correlation coefficient for the 21 pairs of parameters, obtained from 3000 bootstrap re-samplings with a replacement of 10 plants.

\begin{tabular}{|c|c|c|c|c|c|c|c|}
\hline & TWF & MFL & MFWi & MFW & NBP & NFP & NFB \\
\hline $\mathrm{TWF}^{1}$ & & -0.649 & -0.604 & -0.626 & 0.231 & 0.810 & -0.120 \\
\hline MFL & 0.790 & & 0.620 & 0.539 & -0.744 & -0.772 & -0.655 \\
\hline MFWi & 0.845 & 0.987 & & 0.562 & -0.774 & -0.751 & -0.629 \\
\hline MFW & 0.811 & 0.977 & 0.978 & & -0.767 & -0.781 & -0.648 \\
\hline NBP & 0.974 & 0.657 & 0.731 & 0.684 & & 0.384 & -0.686 \\
\hline NFP & 0.995 & 0.698 & 0.773 & 0.712 & 0.980 & & -0.128 \\
\hline NFB & 0.906 & 0.738 & 0.782 & 0.741 & 0.763 & 0.907 & \\
\hline \multicolumn{8}{|c|}{ - } \\
\hline FWB & & -0.507 & -0.472 & -0.321 & 0.201 & 0.864 & -0.179 \\
\hline MFL & 0.865 & & 0.676 & 0.283 & -0.699 & -0.631 & -0.531 \\
\hline MFWi & 0.882 & 0.988 & & 0.329 & -0.709 & -0.633 & -0.526 \\
\hline MFW & 0.921 & 0.964 & 0.969 & & -0.628 & -0.585 & -0.550 \\
\hline NBP & 0.955 & 0.764 & 0.801 & 0.855 & & 0.334 & -0.696 \\
\hline NFP & 0.995 & 0.815 & 0.834 & 0.873 & 0.961 & & -0.184 \\
\hline NFB & 0.910 & 0.806 & 0.838 & 0.832 & 0.643 & 0.911 & \\
\hline
\end{tabular}

${ }^{1} \mathrm{TWF}=$ total weight fruit $(\mathrm{g}), \mathrm{MFL}=$ mean fruit length per plant $(\mathrm{cm}), \mathrm{MFWi}=$ mean fruit width per plant $(\mathrm{cm}), \mathrm{MFW}=$ mean fruit weight per plant $(\mathrm{g})$; NBP $=$ number of bunches per plant, NFP = number of fruits per plant, $\mathrm{NFB}=$ number of fruits per bunch.

\section{REFERENCES}

CARGNELUTTI FILHO, A. et al. Sample size to estimate the Pearson correlation coefficient among characters of castor bean. Semina: Ciências Agrárias, v.33, p.953-962, 2012. Available from: <http://www.scielo.br/pdf/pab/v45n12/v45n12a05.pdf>. Accessed: Feb. 18, 2017. doi: 10.5433/1679 0359.2012v33n3p953.

CARGNELUTTI FILHO, A. et al. Sample size for estimating the Pearson correlation coefficient among corn characters. Pesquisa Agropecuária Brasileira, v.45, n.12, p.1363-1371, 2010. Available from: <http://www.scielo.br/pdf/pab/v45n12/v45n12a05.pdf>. Accessed: Feb. 18, 2017. doi: 10.1590/S0100 204X2010001200005.

CARGNELUTTI FILHO, A. et al. Sample size to estimate the Pearson correlation coefficient among characters of Crambe abyssinica. Revista Ciência Agronômica, v.42, n.1, p.149-158, 2011. Available from: $<$ http://www.scielo.br/pdf/rca/v42n1/v42n1a19.pdf $>$. Accessed: Feb. 18, 2017. doi: 10.1590/S1806 66902011000100019.

CRUZ, C.D.; REGAZZI A.J. Modelos biométricos aplicados ao melhoramento genético. Viçosa: UFV, 1997. 390p.

EMBRAPA. Sistema brasileiro de classificação de solos. Rio de Janeiro: Centro Nacional de Pesquisa de Solos, 2006. 306p.

FERREIRA, D.F. Estatística básica. 2.ed. Lavras: Universidade Federal de Lavras, 2009. 664p.

HAESBAERT, F.M. et al. Sample size for experiments with bean pods in different environments. Ciência Rural, v.41, n.1, p.3844, 2011. Available from: <http://www.scielo.br/pdf/cr/v41n1/ a834cr3400.pdf >. Accessed: Feb. 18, 2017. doi: 10.1590/S0103 84782011000100007 .
HAIR J.F. et al. Análise multivariada de dados. Porto Alegre: Bookman, 2005. 593p.

LÚCIO A.D. et al. Sample size and plot size for growth and productivity characteristics of tomato. Horticultura Brasileira, v.30 n.4, p.660-668, 2012. Available from: $<$ http://www.scielo.br/ pdf/hb/v30n4/v30n4a16.pdf >. Accessed: Feb. 18, 2017.

R Development Core Team. R: a language and environment for statistical computing. Viena: R Foundation for Statistical Computing, 2016. Available from: <http://www.R-project.org $>$. Accessed: Feb. 18, 2017.

ROLAS (REDE OFICIAL DE LABORATÓRIOS DE ANÁLISE DE SOLO E DE TECIDO VEGETAL DOS ESTADOS DO RIO GRANDE DO SUL E DE SANTA CATARINA). Recomendações de adubações e de calagem para os estados do Rio Grande do Sul e Santa Catarina. Passo Fundo: SBCS Núcleo Regional Sul, 2004. 224p.

SANTOS, D. et al. Sample sufficiency for lettuce grown in different environments. Ciência Rural, v.40, n.4, p.800-805, 2010. Available from: <http://www.scielo.br/pdf/cr/v40n4/a554cr1846.pdf>. Accessed: Feb. 18, 2017. doi: 10.1590/S0103 84782010000400009.

SILVA, A.R. et al. Sample size for morphological characterization of pepper fruits. Horticultura Brasileira, v.29, n.1, p.125-129, 2011. Available from: <http://www.scielo.br/pdf/hb/v29n1/22.pdf $>$. Accessed: Feb. 18, 2017. doi: 10.1590/S010205362011000100022.

SILVA, G.O. da et al. Sample size for evaluation of carrot traits in agroecologic cultivation systems. Horticultura Brasileira, v.27, n.2, p.166-170, 2009. Available from: <http://www.scielo.br/pdf/ hb/v27n2/v27n2a08.pdf $>$. Accessed: Feb. 18, 2017. doi: 10.1590/ S010205362009000200008. 